International Journal of English Literature and Social Sciences
Vol-6, Issue-2; Mar-Apr, 2021
Journal Home Page Available: https://ijels.com/
Journal DOI: $10.22161 /$ ijels

\title{
Factors Causing Reticence for Non-English Majored Students in Speaking Performance
}

\author{
Le Van Tuyen, Nguyen Ha Linh Phuong
}

Ho Chi Minh City University of Technology (HUTECH) - Ho Chi Minh City, Vietnam

Received: 09 Jan 2021; Received in revised form: 06 Mar 2021; Accepted: 26 Mar 2021; Available online: 19 Apr 2021

(C)2021 The Author(s). Published by Infogain Publication. This is an open access article under the CC BY license

(https://creativecommons.org/licenses/by/4.0/).

\begin{abstract}
Among the four macro skills, speaking skill is always considered to be challenging to most students at all levels of education, including tertiary level because there are many factors may prevent them from improving their speaking skill. Therefore, this study aims to explore the extent of reticence of non-English majored students in English speaking performance in class as well as to investigate the factors which cause reticence in their English speaking performance at a university in Ho Chi Minh City-Vietnam (hereafter called HCMU). The instruments used for collecting data were questionnaire surveys, semistructured interviews, and class observations. The participants of the study were 147 non-English majored students. The findings of the current revealed that most of the students felt reticent about speaking English performance in class. Furthermore, the study showed that context-related factors such as the text-book and the class environment caused more speaking reticence for non-English majored students than the other factors. Last but not least, several pedagogical implications were provided not only for teachers and students at HCMU to improve students' speaking performance but also reduce their reticence in English speaking classes.
\end{abstract}

Keywords—speaking performance, reticence, non-English majors, English classes, tertiary level.

\section{INTRODUCTION}

Nowadays English is commonly taught and learned at all levels of education in Vietnam. Hutchinson and Waters (1987) indicated that English creates a new generation of students and it becomes the language of commerce and technology which is internationally accepted. Therefore, mastering English is very essential for students to increase their knowledge, receive technological industry, and find a well-paid job in the future.

Mastering English means to be able to speak or use it. However, being able to speak English fluently is not easy at all; many foreign language students are reticent about learning speaking skills. Reticence is one of the highlighted factors that mainly impact students' Englishspeaking performance. Reticence may be caused by several factors. For example, students choose to be silent as a reaction to all the questions of the teacher during the lessons and they are susceptible to reticence. It is hard for students to escape from reticence or anxiety. Especially, they fear communication (Muhammad, 2020). Reticence in speaking performance may result from the fact that oral language development has been ignored in the classroom. Moreover, oral language is more used by teachers than by students in the classroom most of the time (Al Hosni, 2014). Students still do not have chances to improve their speaking performance in terms of fluency due to the impact of reticence when they speak English. Some other factors that can make them reticent are being not familiar with the topics, feeling nervous or embarrassed when being laughed at by their friends, having no chance to frequently practice their speaking skills, and being afraid of losing their face, etc. Speaking English is also a problem with non-English majored students at HCMU. No matter how much they know about the English language, they still seem to be reticent during speaking classes. As a result, although the teachers always try to use various active teaching methods, students are still not motivated enough to communicate in English in speaking classes. Thus, the current study was conducted to explore the extent of reticence among non-English majored students and discover the factors which cause reticence for them in English speaking performance. To achieve the above 
objectives, this study attempts to address the following two research questions:

1. To what extent are non-English majored students reticent about English speaking performance in class?

2. What factors cause reticence for non-English majored students in English speaking performance?

This study is expected to provide an insight into the English-speaking reticence area, and help teachers understand the factors that affect their students' reticence in English speaking performance, thus they will have better solutions to reduce the extent of reticence among students in English classes.

\section{BRIEF LITERATURE REVIEW}

\subsection{Reticence and Symptoms of Speaking Reticence}

Hedge (2000) argued that like other language skills, speaking skill requests special care because it is a skill whereby the students are recognized not only from how they are thinking but also from what they are saying. It is entirely true that many researchers view speaking and speaking reticence from different perspectives.Speaking reticence or communication apprehension are terms that refer to a fear encountered by students when speaking to many people or a person and both terms are also used interchangeably. Horwitz et al. (1986) maintain that speaking reticence is a shyness type that typified by reticence or fear of communicating with other people.

There are some symptoms of reticence that can be seen.

Physiological Symptoms: According to Wrench et al. (2012), speaking reticence is associated with many physical symptoms, and these symptoms are clearly observed on students' bodies. In particular, students usually observe their hands feeling wet, their heartpounding, and their legs quivering. Moreover, it is noticed that a hard articulation for simple words might be caused because of the dry mouth, shaking voice, and rapid breathing. Students cannot control their movements as well as their thoughts, and it is hard for them to balance between them.

Behavioral Symptoms: When a student experiences speaking reticence, other behavioral symptoms are observed. Particularly, avoiding the speaking situation is the first common behavior of the students who have an extremely high level of speaking reticence. McCroskey (1976) stated that students, who are disabled by speaking reticence, would avoid communication much of the time. However, this does not mean that they would never engage in interaction. In direct interaction with others, the students with speaking reticence prefer to keep silent. Moreover, they are also unsure about expressing their opinions as well as their ideas, and they usually define the questions of others as criticisms. Furthermore, according toBurgoon (1976), the speaking reticent students feel unsafe and not good enough when communicating. Additionally, they are not only shy but also embarrassed when sharing the same views with others, so they prefer to remain silent most times and show their unwillingness to communicate.

Psychological Symptoms: There are some psychological or mental symptoms of speaking reticence that commonly experienced by the students. According to Kanar (2011), some mental symptoms, which are negative self-talk, speaking reticence, confused thoughts, and deficiency feeling, characterized the students who encounter reticence in speaking. On one hand, Kanar (2011) also stated that when students begin to speak, they have not only some physical symptoms but also psychological ones. In particular, students who suffer the mental symptoms before speaking become "tongue-tied". On the other hand, Achbi and Sebaa (2011) claimed that these students are fine once when starting to speak.

\subsection{Causes of Speaking Reticence}

\subsubsection{Personal Causes}

Personality:According to McCroskey et al. (1977), the construct of communication nervousness is represented by oral communication nervousness. Particularly, high oral communication nervousness is related to low self-esteem. Moreover, students with low self-esteem probably have high-level reticence in speaking situations because they think that they do not have enough language knowledge, so they lack performance confidence and fear of losing their face. Therefore, students have no will to communicate in class as well as are reticent all the time. According to Wrench et al. (2012), students with such personality and their trait reticence feel more apprehensive when completing any speaking tasks regardless of the context or audience. Besides, other personal elements not only affect their reticence but also make them nervous to speak.

Lack of Vocabulary: When the students are speaking, they need to select appropriate words and accurate expressions in order to enhance their oral skills. According to Thornbury (2005), words and expressions get a relatively high proportion in spoken language. In addition, the limited words and expressions when the students try to express their opinions frequently struggle with their speaking performance in English. Students with a limited vocabulary amount can hesitate to speak a foreign language because they cannot express completely their ideas. In the study of Liu (2007), he acknowledged that the 
lack of vocabulary is the principal cause of students' speech reticence in foreign languages classroom, some participants state that they are a little shy and afraid of speaking because their vocabulary is poor, so they often feel anxiety when speaking in front of other classmates. As a result, the lack of vocabulary creates speaking reticence and has a negative effect on the participation of the students in speaking activities.

Fear of Making Mistakes:In the classroom, one of the main factors of students' hesitancy to speak in English is the fear of making mistakes (Tsui cited in Nunan, 1999; Robby, 2010). Aftat (2008) stated that this fear is connected to negative judgment and correction issues because they do not want to be looked foolish in front of other students (Kurtus, 2001). Additionally, the fear of being blasted by the teacher as well as being laughed at by other students also influences the speaking progress of a student in the class. Therefore, the students do not want to participate in the speaking activities (Nguyen, 2011). In an EFL context like in Vietnam, the students' fear of making English-speaking mistakes including the grammatical mistake and the pronunciation mistakes are the main barriers faced by the EFL students and prevents them to develop their speaking capacity in English.

Shyness: When the students are required to speak English in the class, they are able to suffer from shyness which is an emotional thing. Gebhard (2000) noted that shyness not only could be a source of the problem in the learning activities of the students in the English class but also plays a significant role in their speaking performance. Additionally, Saurik (2011) identified that the students think they will make mistakes and be laughed at by their peers, so they feel very shy when talking in English.

\subsubsection{Interpersonal Causes}

Competition:Students will compare themselves with the other classmates so competition is considered as another factor that can create students' speaking reticence in the classroom. They have a lack of confidence when having a lower level than their classmates. According to Wrench et al. (2012), the level of speaking reticence can be influenced greatly by the perceived similarity degree between students and their classmates. Moreover, Young (1991) determines that one of the factors causing reticence in students' speaking performance is competition.

Laugh at Students' Utterances:Laughing at students' opinions, mistakes, as well as their pronunciation, creates makes them uncomfortable in continuing the speech. Moreover, it also prevents the students' ability to volunteer when answering teachers' questions. In the study of Liu (2007), one of his students states that she will lose her confidence when she is in front of others and cannot say any words because she is afraid of making mistakes and being laughed at by her classmates. Furthermore, learners' interaction between teachers, other learners, and course content are defined as critical forms in education (Garrison \& Shale, 1990).

Teachers' Behavior:Teachers' behavior consists of giving feedback, explanations, encouragement as well as providing chances for students to talk and it can contribute a strong impact on students' reticence in speaking performance. In this case, they will feel embarrassed and be reticent in speaking when they are corrected by the teacher because they feel so nervous and "dumb" (Young, 1991). Additionally, some teachers in the classroom consider their role as the controller who constantly corrects students and does not let their students work in groups or pairs because they fear that the class cannot be wellcontrolled. As a result, the students are afraid of talking with their teachers and this may create a great deal of students' speaking reticence.

Classroom Atmosphere:The classroom atmosphere is defined as the mood, climate, or emotion contributed by the groups in class, which can reveal the participation of all students in class. Furthermore, McCombs and Whisler (1997) asserted that "learning occurs best in an environment that contains positive relationships and interaction and in which the learner feels appreciated, acknowledged, respected and validated" (p.51). According to three researchers including Pattapong (2010), Peng (2014), and Suksawas (2011), a boring or quiet classroom atmosphere can demotivate the speaking willingness of students while a friendly one can promote their willingness to communicate. Therefore, the classroom atmosphere has a huge impact on the students' reticence in speaking performance.

\section{RESEARCH METHODS}

\subsection{Participants}

This study was conducted at HCMU. The participants were 147 second-year students from 4 classes. Their age ranges from 18 to 26. They major in Marketing (57.8\%) and Business Administration (42.2\%). All of them have finished at least 1 year of learning English. Moreover, 3 out of 4 classes were observed to collect more data for the study.

\subsection{Research Instruments}

Three research instruments were employed for collecting data for the current study, including questionnaires, semi-structured interviews, and class observations.

The questionnaire for student participants consists of 62 items aiming to explore the students' perceptionsof the 
reticence when speaking English in class. The questionnaire items were adapted from several studies and developed from literature (Fang-yu, 2011; Hamouda, 2013; Soo \& Goh, 2013; Dao, 2017; Tavakoli\&Davouli, 2017; Le \& Tran, 2020). It consists of three parts. Part I consists of 4 items asking students to give their personal information, including their gender, age, their experience in learning English as well as their majors. Part II consists of 18 items using a five-point Likert scale ranging from ' 1 ', for Not At All True to ' 5 ' for Always True. It is used to measure the extent of students' reticence were considered.Part III consists of 40 items, using a four-point Likert scale ranging from ' 1 ' for Strongly disagree to ' 4 ' for Strongly agree in order to avoid neutral responses. It was used to explore the factors causing students' reticence. After being piloted, the questionnaire for the students was revised and the final versions were used for collecting data.

The semi-structured interview was chosen to demonstrate more of the students' insights into the main factors causing their speaking reticence. Furthermore, all the questions for the interview were translated into Vietnamese to be obviously understood by the students. Before officially conducting the interview, a pilot interview was carried out to ensure that all the questions were not only obvious but also obtain essential information.
Class observation allowed the researcher to understand what is occurring in the context with the aim of finding out the extent of the students' speaking reticence, andfactors causing their speaking reticence. Data collected from classroom observation was used to support the quantitative data which were collected from the questionnaires.

\subsection{Data Collection}

Data collection took place during the first term of the academic year 2020-2021. For the questionnaire, 160 questionnaire copies in Vietnamese were administered to the students of the 4 classes after being piloted with 10 students who were not involved in the study. However, 153 copies were returned and 6 copies of them were answered incompletely. It took about 20 minutes for the participants to go all over the questions and discussions. For the interview, it took each student 20 - 30 minutes to answer the interview questions. All the interviews were recorded fully so that the collected interview information was perfect and full. Furthermore, the researcher also took notes during each interview. Regarding class observations, three classes were observed to discover what was happening to the students during the speaking sessions and how they behaved towards speaking activities. For each class, the researcher took open-ended notes and wrote down what occurred during the class into an observation scheme. The table below shows the schedule of class observations.

Table1. Class observation schedule

\begin{tabular}{|l|l|l|l|l|l|}
\hline Class code & Class & Date & Time & Course title & Section \\
\hline CL1 & 19DTMA2 & March $5^{\text {th }}, 2021$ & 90 minutes & English 3 & 1A, 1B \\
\hline CL2 & 19DHQB2 & March $6^{\text {th }}, 2021$ & 90 minutes & English 3 & 2A, 2B \\
\hline CL3 & 19DTCA2 & March $8^{\text {th }}, 2021$ & 90 minutes & English 4 & 8A, 8B \\
\hline
\end{tabular}

\subsection{Data Analysis}

For data obtained from the questionnaires, descriptive statistics was used. SPSS Statistics version 22.0 was employed to calculate the mean scores $(\mathrm{M})$ as well as the standard deviation (SD). The meaning of the mean (M) scores for students' level of reticence in their speaking performance were interpreted based on the scales as follows: Five-point Likert-scale of extent:1.00 - 1.80: Never true; 1.81 - 2.60: Rarely true; 2.61 - 3.40: Sometimes true; 3.41 - 4.20: Often true; 4.21 - 5.00: Always true; and for factors causing reticence, four-point Likert-scale of agreement: 1.00 - 1.75: Strongly disagree; 1.76 - 2.50: Disagree; 2.51 - 3.25: Agree; 3.26 - 4.00: Strongly agree was used. For qualitative data which were collected from individual semi-structured interviews and observations, content analysis was used. The students were coded as S1, S2, S3 ... to S10, and classes were coded CL1-CL2- CL3.

\section{RESULTS AND DISCUSSION}

\subsection{Results}

\subsubsection{The extent of students' reticence in English speaking performance}

Research question 1 aimed to examine the extent of students' reticence in English speaking performance. The data collected from the questionnaire as well as semistructured interviews are presented as follows:

The results of the descriptive statistics from the questionnaire as can be seen in Table 2 showing that the total mean scores of the extent of students' reticence were rather high $(\mathrm{M}=3.61 ; \mathrm{SD}=.814)$. 


\begin{tabular}{lllll}
\hline \multirow{2}{*}{ No. } & Items & N=147 & \\
\cline { 3 - 4 } & & $\mathbf{M}$ & SD \\
\hline 1 & I feel nervous and avoid seeing my teacher's face in class. & 3.78 & .807 \\
\hline 2 & I am afraid of being invited to speak. & 3.77 & .768 \\
\hline 3 & I feel comfortable when keeping silent and listening. & 3.52 & .902 \\
\hline 4 & $\begin{array}{l}\text { I do not dare to say or answer the question even if I have } \\
\text { ideas. }\end{array}$ & 3.71 & .901 \\
\hline 5 & I don't dare to ask my teacher questions in English. & 3.69 & .833 \\
\hline 6 & I never volunteer to answer my teachers' questions. & 3.46 & .901 \\
\hline 7 & I feel comfortable when working individually. & 3.75 & .818 \\
\hline 8 & I always wish not to be called by my teacher. & 3.78 & .783 \\
\hline 9 & I rarely ask my classmates questions in English in class. & 3.54 & .813 \\
\hline 10 & $\begin{array}{l}\text { I never communicate with my teacher in English before and } \\
\text { after class. }\end{array}$ & 3.59 & .826 \\
\hline 11 & I am nervous when there are speaking activities. & 3.39 & .816 \\
\hline 12 & I feel nervous if I speak English in the group. & 3.43 & .767 \\
\hline 13 & $\begin{array}{l}\text { I feel tense when the teacher organizes pair work or group } \\
\text { work for speaking activities. }\end{array}$ & 3.52 & .779 \\
\hline 14 & $\begin{array}{l}\text { I feel less comfortable answering the teacher's questions in } \\
\text { front of my classmates. }\end{array}$ & 3.59 & .756 \\
\hline 15 & $\begin{array}{l}\text { To avoid any embarrassing situation, I always prefer } \\
\text { remain silent rather than to speak English in class. }\end{array}$ & 3.77 & .828 \\
\hline 16 & $\begin{array}{l}\text { I am always worried about what other classmates think about } \\
\text { me when I speak up English in class. }\end{array}$ & 3.67 & .779 \\
\hline $\begin{array}{l}\text { In order not to participate in the English class's activities, I } \\
\text { prefer to sit at the back rows. }\end{array}$ & 3.69 & .738 \\
\hline $\begin{array}{l}\text { I feel my heart pounding when I am going to be asked to } \\
\text { speak in English class. }\end{array}$ & 3.40 & .849 \\
\hline
\end{tabular}

As can be seen in Table 2, all items except item 11 and item 18 had the mean score ranging from 3.41-4.20, which indicates that these items were often true for most students. More specifically, the qualitative data from the interview was also taken into account to attain throughout information about the extent of students' reticence in English speaking performance. In particular, the two highest means belong to item $1(\mathrm{M}=3.78 ; \mathrm{SD}=.807)$ and item $8(\mathrm{M}=3.78 ; \mathrm{SD}=.783)$, which mean a large number of students felt nervous and avoided seeing their teacher's face in class (item 1) as well as they also wished not to be called by their teacher (item 8 ). In the interview, students also expressed their issues in being anxious when speaking English in class, for example:

"I like listening skill and dislike speaking skill because my pronunciation is not good and correct to be understood by my English teacher. Therefore, I do not want to speak in English." (S1)

Besides, the two second highest mean scores belong to students' afraid feelings of being invited to speak (item 2: $\mathrm{M}=3.77 ; \mathrm{SD}=.768$ ) and their silent remaining rather than speaking English in class to avoid any embarrassing situations (item 15: $\mathrm{M}=3.77 ; \mathrm{SD}=.828$ ). Here are some obvious opinions of the students:

"I feel really anxious when sitting in my English classes because I do not understand my English teacher; andI dislike speaking skill because I am afraid of being laughed by other classmates when incorrectly speaking in English. In addition, I am not confident about my pronunciation" (S7); "I feel nervous when taking part in my English classes because my English ability is not good enough to communicate." (S4).

Additionally, most students felt comfortable when working individually (item $7: \mathrm{M}=3.75 ; \mathrm{SD}=.818$ ) and did not dare to say or answer the question even if they had ideas (item 4: $\mathrm{M}=3.71 ; \mathrm{SD}=.901)$. For example, several students expressed:

"I think my speaking ability is not good enough to communicate with my classmates when working in group." (S1); 
"In English class, I never talk to my friends in English. However, I still need to answer some questions in English of my teacher." (S4); "I rarely speak in English with my friends. Particularly, I just speak with my English teacher in English if I have to answer her questions." (S2)

Moreover, they did not dare to ask their teacher questions in English (item 5: $\mathrm{M}=3.69 ; \mathrm{SD}=.833$ ) and preferred to sit at the back rows in order not to participate in the English class's activities (item 17: $\mathrm{M}=3.69 ; \mathrm{SD}=.738$ ). Some evident examples are as follows:

"In my English class, I never speak or ask my teacher in English because of my poor communication skill." (S6); "I infrequently speak in English during my English class and I need to try very hard to express my ideas in English with other classmates when completing several speaking tasks of my teacher." (S3)

The next high mean score goes for item $16(\mathrm{M}=3.67$; $\mathrm{SD}=$ .779) which means that students were always worried about what other classmates thought about them when they spoke up English in class. S8 shared his idea about this problem:

"I often speak in English only with my teacher in any situation because my English teacher is the only one who can understand what I am saying. Therefore, it is more comfortable for me to interpret my opinions as well as my feelings." (S8)

In addition, two other items with the same mean score, which were often true for most students, are they never communicated with their teacher in English before and after class (item 10: $\mathrm{M}=3.59 ; \mathrm{SD}=.826$ ), and they felt less comfortable answering the teacher's questions in front of their classmates (item 14: $\mathrm{M}=3.59 ; \mathrm{SD}=.756$ ). For instance, several students expressed their ideas as follows:

"I never feel confident enough about my speaking ability. Especially, I always feel so stressful every time speaking in English in front of my classmates and my English teacher." (S3)

"I often feel nervous when being asked to present in English in front of a crowd or other classmates." (S6)

Furthermore, a large number of students rarely asked their classmates questions in English in class (item 9: $\mathrm{M}=3.54$; $\mathrm{SD}=.813$ ) or they felt comfortable when keeping silent and listening (item 3: $\mathrm{M}=3.52 ; \mathrm{SD}=.902$ ) as well as felt tense when the teacher organized pair work or group work for speaking activities (item 13: $\mathrm{M}=3.52 ; \mathrm{SD}=.779$ ). In accordance with the survey, the students also revealed the same problems:

"I personally think my speaking skill is really bad and I cannotask my classmates or say anything to them in English because of my terribleintonation." (S6); "I rarely correspond in English except some compelled situations such as working group projects or taking an oral test with my English teacher." (S8)

Additionally, students also never volunteered to answer their teachers' questions (item 6: $\mathrm{M}=3.46 ; \mathrm{SD}=.901$ ) and they felt nervous if they spoke English in the group (item 12: $\mathrm{M}=3.43 ; \mathrm{SD}=.767)$. For example, some students considered:

"I just want to speak with my best friend in English in some situations such as working in groups, having a group presentation in English, and playing speaking games." (S8); "I always feel nervous when talking to my teacher or foreigners on the street in English. However, it is much easier for me to communicate in English with my friends in my English class." (S2)

Last but not least, two items that were sometimes true for students are item 11 and item 18, which particularly means they were sometimes nervous when there were speaking activities (item 11: $\mathrm{M}=3.39 ; \mathrm{SD}=.816$ ) and they sometimes felt their heart pounding when they were going to be asked to speak in English class (item 18: $\mathrm{M}=3.40$; $\mathrm{SD}=.849$ ). Several students also shared their opinions about this problem as follows:

"I can totally feel my heart pounding every time I am going to be asked to take part in speaking tasks as well as answer several questions of my teacher in English." (S7); "I feel a little bit anxious when speaking in English with other people. It is quite difficult for me to elaborate in some reallife situations that I need to communicate not only with my classmates and my teacher in speaking activities in class but also with native speakers." (S1)

The data collected from three class observations reflected the real situations of the students' English-speaking performance. In particular, most of the students seemed to be passive when participating in speaking activities during the session. Furthermore, they needed more time to not only complete the speaking tasks but also answer the questions of their teacher. Moreover, some of them expressed their anxious feelings when being asked to perform in English in front of other classmates by their 
teacher. Therefore, the more passive in class, the more reticent they were.

In conclusion, it can be concluded that the extent of the students in their English-speaking performance was expressed clearly through the data which were collected from the questionnaires, semi-structured interview, and class observations and that most of the students were reticent about speaking English to a rather high extent.

4.1.2 The factors causing reticence for non-English majored students in English speaking performance

Research question 2 attempted to explore the factors causing reticence for non-English majored students in English speaking performance at HUTECH including student-related factors, classmate-related factors, teacherrelated factors, and context-related factors. The data, which were collected through questionnaires and interviews, were presented below with the aim of exploring these factors. These data were analyzed and discussed descriptively as follows:

Student-related factors

Table 3.Descriptive statistics of student-related factors

\begin{tabular}{|c|c|c|c|}
\hline \multirow{2}{*}{ No. } & \multirow{2}{*}{ Items } & \multicolumn{2}{|c|}{$\mathrm{N}=147$} \\
\hline & & $\mathbf{M}$ & SD \\
\hline 1 & I do not have any motivation to express myself in English. & 3.52 & 612 \\
\hline 2 & I am not interested in English. & 3.39 & .716 \\
\hline 3 & $\begin{array}{l}\text { My passive attitude towards learning English prevents me } \\
\text { from speaking. }\end{array}$ & 3.53 & .655 \\
\hline 4 & $\begin{array}{l}\text { I don't attend English classes regularly, so I feel nervous and } \\
\text { unconfident in the next class. }\end{array}$ & 3.49 & .656 \\
\hline 5 & $\begin{array}{l}\text { I rarely prepare my lessons or read materials in advance } \\
\text { before coming to class. }\end{array}$ & 3.61 & .603 \\
\hline 6 & $\begin{array}{l}\text { I don't understand what I am saying as well as what my } \\
\text { teacher is saying. }\end{array}$ & 3.57 & .561 \\
\hline 7 & I don't understand every word the English teacher says. & 3.41 & 670 \\
\hline 8 & $\begin{array}{l}\text { My pronunciation is not clear enough for my teacher and } \\
\text { classmates to understand what I say. }\end{array}$ & 3.50 & .666 \\
\hline 9 & $\begin{array}{l}\text { My grammar knowledge is not good enough for me to say } \\
\text { correct sentences. }\end{array}$ & 3.55 & .674 \\
\hline 10 & My English proficiency is low. & 3.40 & .689 \\
\hline 11 & My English vocabulary is poor. & 3.38 & .734 \\
\hline 12 & $\begin{array}{l}\text { I usually make mistakes in speaking English, which prevents } \\
\text { me from participating in speaking activities. }\end{array}$ & 3.30 & .762 \\
\hline
\end{tabular}

As can be seen in Table 3, all items had mean scores ranging from 3.26 - 4.00, which indicates that most students strongly agree that these factors significantly affect their English-speaking reticence in class.

As illustrated in Table 3, the students' reticence in English speaking performance was caused by a set of factors relating to students' motivation and attitudes(items 1, 2, 3, $4, \& 5)$ and to students' English proficiency and knowledge (items 6, 7, 8, 9, 10, 11, \& 12).

In regards to students' motivation, the students said that they did not have enough motivation as well as the confidence to express themselves in English (item 1) with $\mathrm{M}=3.52$ and $\mathrm{SD}=.612$. Therefore, the lack of motivation might be the indicator that draws students into a reticent state when expressing their ideas in English. Besides, in regards to students' attitudes, another factor that might often cause students' speaking reticence is the passive attitude towards learning English which prevented them from speaking (item 3 ) with $\mathrm{M}=3.53$ and $\mathrm{SD}=.655$. In the interview, several students also shared their opinions about this problem as follows:

"In my opinion, it is because of the habit of using mynative language, Vietnamese. Furthermore, I am also lazy to use English in class as well as in real-life situations." (S2); "I think the unfamiliarity of speaking perform in English in front of a lecture hall, and the demotivation when expressing themselves in English, are two main causes that create the speaking reticence of the students." (S10)

Moreover, the students considered that they did not attend English classes regularly, so they felt nervous and unconfident in the next class (item 4) with $\mathrm{M}=3.49$ and $\mathrm{SD}=.656$. The next factor relating to their attitudes is their rare preparations for the lessons or reading materials 
in advance before coming to class (item 5) with $\mathrm{M}=3.61$ and $\mathrm{SD}=.603$. For example, some student gave their comments as follows:

"To my mind, because I rarely attend to my English classes so I think the lack of opportunities to practice speaking frequently in English is the main factor." (S3); "I never prepare for the next lesson before coming to my English class, because I think it is not important enough for me to do that. However, I also consider that it makes me feel more nervous in the next class." (S2)

The last item relating to the students' motivation and attitudes, which less affected their reticence in English speaking performance, was their interests in English (item 2) with $\mathrm{M}=3.39$ and $\mathrm{SD}=.716$. Here are some obvious opinions of the participants:

In regards to students' English proficiency and knowledge, the students agreed that they did not understand what they were saying as well as what their teacher was saying, so they were not willing to say anything in English (item 6) with $\mathrm{M}=3.57$ and $\mathrm{SD}=.561$. Besides, they also did not understand every word their English teacher said (item 7) with $\mathrm{M}=3.41$ and $\mathrm{SD}=.670$. Here are some obvious opinions of the students:

"I believe that the fear of communicating with native speakers and the misunderstanding their teachers or classmates are the two main reasons that make students reticent." (S6); "I assume that students do not want to speak in English if they feel their speaking level is too low, and sometimes they cannot understand what they are saying." (S7)

Nonetheless, another two individual factors that cause students' reticence in their speaking performance including the unclear pronunciations of the students, which were not clear enough for their teacher and classmates to understand what they said (item 8 ) with $\mathrm{M}=3.50$ and $\mathrm{SD}=.666$, and their poor grammar knowledge, which was not good enough for them to say correct sentences (item 9) with $\mathrm{M}=$ 3.55 and $\mathrm{SD}=.674$. For example, many students also expressed their opinions about this problem as follows:

"In my view, the bad intonation and poor pronunciation make students feel anxious in speaking. As a result, they do not want to speak in English anymore." (S3); "I personally consider that the lack of natural pronunciation as well as the anxiety of being laughed when communicatingin English wrongly are two factors create students' speaking reticence. In addition, I personally think that lack of vocabulary as well as poor pronunciation is two common factors that create reticence in my speaking performance." (S1)

Moreover, students strongly agreed that their low English proficiency might often create reticence when expressing themselves in English (item 10) with $\mathrm{M}=3.40$ and $\mathrm{SD}=$ .689. The next factor might make students feel reticent when communicating in English is their poor English vocabulary (item 11 ) with $\mathrm{M}=3.38$ and $\mathrm{SD}=.734$. In accordance with the survey, the students also revealed same problems:

"From my point of view, the fear of making grammatical mistakes and the panic of failing an English test can create the reticence in students' speaking performance." (S1); "Personally, I think mylack of English vocabulary is the main factor." (S8); "My poor vocabulary can create reticence in my speaking performance." (S3); "I think the poor English vocabulary, the lack of using appropriate grammar structures, and reallife communication situations are three principal factors." (S6)

Lastly, the only individual factor that sometimes caused speaking reticence among students is "making mistakes in speaking English" (item 12) with $\mathrm{M}=3.30$ and $\mathrm{SD}=.762$. In the interview, many students agreed with this finding. For example:

"From my standpoint, the frequency of making repeated pronunciation mistakes is the most fundamental factor that causes my reticence in English speaking performance." (S10); "Personally, I think the consideration of using incorrect grammar structures is the principal factor that easily makes students feel uncomfortable when speaking in English.'

The data collected from three class observations also revealed that several factors caused reticence among students. For example, when observing CL1 on March 5th, 2021, the researcher discovered that the students did not have enough time for practicing their speaking skill in class, most of them were not willing to participate in the communicative activities in class, and several did not remember the vocabulary to express their opinion in English. Therefore, they took more time to think and had many pauses during their speaking performance. In addition, most of the students in class used a lot of 
Vietnamese when they needed to work in groups or pairs, and some of them were shy when answering their teacher in front of the class.

Classmate-related factors

Table 4.Descriptive statistics of classmate-related factors

\begin{tabular}{lllll}
\hline \multirow{2}{*}{ No. } & Items & \multicolumn{2}{l}{$\mathbf{N = 1 4 7}$} \\
\cline { 4 - 5 } & $\mathbf{M}$ & SD \\
\hline 13 & $\begin{array}{l}\text { I am afraid of being seen as foolish by my classmates if I } \\
\text { make too many mistakes when I speak in class. }\end{array}$ & 3.44 & .786 \\
\hline 14 & $\begin{array}{l}\text { I am afraid that other classmates will laugh at me if I make } \\
\text { some mistakes. }\end{array}$ & 3.37 & .777 \\
\hline 15 & $\begin{array}{l}\text { My classmates would laugh at me if my answer to the } \\
\text { teacher's question is wrong. }\end{array}$ & 3.49 & .666 \\
\hline 16 & $\begin{array}{l}\text { I am worried of losing face and being criticized by } \\
\text { classmates. }\end{array}$ & 3.31 & .755 \\
\hline 17 & $\begin{array}{l}\text { Every time I volunteer to answer my teacher's questions in } \\
\text { class, I feel that other classmates think I am showing off. }\end{array}$ & 3.39 & .736 \\
\hline 18 & I think that my classmates' English is better than mine. & 3.53 & .665 \\
\hline
\end{tabular}

Data displayed in Table 4 reflected the descriptive statistics of classmate-related factors that affected students' reticence in speaking performance. More specifically, the findings revealed that the students strongly agreed that they were afraid of being seen as foolish by their classmates if they made too many mistakes when they spoke in class (item 13) with $\mathrm{M}=3.44$ and $\mathrm{SD}=$ .786. Furthermore, they said that their classmates would laugh at them if their answers to the teacher's question were wrong (item 15) with $\mathrm{M}=3.49$ and $\mathrm{SD}=.666$. Particularly, several students claimed about the situation:

"From my point of view, two predominant factors cause reticence include the fear of speaking incorrectly and the scare of being laughed by other classmates when making too many mistakes in class." (S8); "Personally, I think a student can be readily impacted by their other classmates' passive attitudes such as being laughed or being seen foolish." (S6)

In addition, most of them thought that they their classmates' English was better than theirs (item 18) with $\mathrm{M}=3.53$ and $\mathrm{SD}=.665$. In the interview, many students agreed with this:

"The higher level of other classmates makes me do not want to speak in English." (S7); "In my opinion, I personally determine that some students, who have good English competence, can make other students whose English abilities are lower feel stressful. Therefore, these students do not want to communicate in English in class." (S3)

Moreover, the students were afraid that other classmates would laugh at them if they made some mistakes (item 14) with $\mathrm{M}=3.37$ and $\mathrm{SD}=.777$. For example, regarding to this problem, $\mathrm{S} 10$ revealed his idea as follows:

"Students are unable to speak in English if they need to communicate with other classmates whose English level is higher because they feel embarrassed when making speaking mistakes." (S10)

Nearly the same number of the students felt that other classmates thought they were showing off every time they volunteered to answer their teacher's questions in class (item 17) with $\mathrm{M}=3.39$ and $\mathrm{SD}=.736$. In particular, some students expressed their agreement on this situation as follows:

"From my point of view, the attitude of other classmatescauses reticence in speaking." (S9); "In my opinion, a class with too many students makes students shy and nervous when volunteering to answer some questions in English." (S8)

Nonetheless, they were worried of losing face and being criticized by classmates (item 16 ) with $\mathrm{M}=3.31$ and $\mathrm{SD}=$ .665. For example, some students revealed their opinion about this problem as follows:

"I consider that the scornfulattitudes of other classmates are the main factors that cause students' speaking reticence because studentseasily feel shy in performing in English in front of the class." (S1); "From my standpoint, I think that the opinion and the recommendations of other classmates are the remarkable causes of students' speaking unwillingness." (S5).

The data collected from the three-class observations revealed that most of the students felt embarrassing in front of their classmates when having the wrong answer. 
Moreover, students frequently waited for the help of other classmates to answer the questions of their teacher in class. Particularly, when observing CL3 on March 8th, 2021, the researcher discovered that the students rarely used English to communicate in class because the habit of using
Vietnamese in English class of their friend strongly affected their attitudes toward learning English. As a result, the students felt more reticent when they were asked to perform or express their ideas in English.

Teacher-related factors

Table 5:Descriptive statistics of teacher-related factors

\begin{tabular}{|c|c|c|c|}
\hline \multirow{2}{*}{ No. } & \multirow{2}{*}{ Items } & \multicolumn{2}{|c|}{$\mathrm{N}=147$} \\
\hline & & $\mathbf{M}$ & SD \\
\hline 19 & $\begin{array}{l}\text { My teacher always assesses my speaking ability instead of } \\
\text { teaching me how to speak. }\end{array}$ & 3.57 & .619 \\
\hline 20 & $\begin{array}{l}\text { My teacher does not give me enough time to find the answer } \\
\text { to her questions. }\end{array}$ & 3.41 & .701 \\
\hline 21 & $\begin{array}{l}\text { My teacher has no interesting methods of teaching speaking } \\
\text { skills. }\end{array}$ & 3.22 & .824 \\
\hline 22 & $\begin{array}{l}\text { Not many opportunities are provided for me to practice } \\
\text { speaking in the class. }\end{array}$ & 3.52 & .612 \\
\hline 23 & My teacher will correct every mistake I make. & 3.41 & .700 \\
\hline 24 & My teacher only asks students to speak in front of the class. & 3.46 & .644 \\
\hline 25 & $\begin{array}{l}\text { My English teacher does not respect what I say and respond } \\
\text { in a friendly way. }\end{array}$ & 3.43 & .682 \\
\hline 26 & My teacher never accepts my ideas when they are wrong. & 3.60 & .627 \\
\hline 27 & $\begin{array}{l}\text { My teacher has negative gestures and harsh comments on my } \\
\text { performance. }\end{array}$ & 3.39 & .677 \\
\hline 28 & My teacher always interrupts me to correct mistakes. & 3.63 & .588 \\
\hline 29 & My teacher always forces me to speak as quickly as possible. & 3.71 & .468 \\
\hline 30 & My teacher creates a stressful atmosphere in the English class. & 3.64 & .561 \\
\hline 31 & My teacher does not encourage me to speak English in class. & 3.27 & .770 \\
\hline
\end{tabular}

Data displayed in Table 5 revealed that most of the students strongly agreed that 13 above-proposed items about teacher-related factors might often causestudents' reticence in their English speaking performance.

As illustrated in Table 6, the students' reticence in English speaking performance was also caused by a set of teacherrelated factors including: 6 items relating to teachers' teaching methods (items 19, 20, 21, 22, 23 \& 24)

and7 items relating to teachers' attitudes and behaviors (items 25, 26, 27, 28, 29, 30 \& 31).

In regards to teachers' teaching methods, the students realized that teaching methods had a major influence on the reticence in speaking performance of them. More specifically, they also said that their teacher always assessed their speaking ability instead of teaching them how to speak (item 19 ) with $\mathrm{M}=3.57$ and $\mathrm{SD}=.619$. In the interview, $\mathrm{S} 2$ agreed with this:

"There are many factors related to the teacher, but one of the most principal factors is the lack of enthusiasm in English teaching progress. Particularly, he or she never socializes with the students to teach them how to speak as well as help them feel more interested in learning English." (S2)

In addition, the next two factors relating to the teaching methods of the teacher, which had the same meaning are item 20 and item 23. Particularly, most of the students agreed that they felt reticent in speaking because their teacher did not give them enough time to find the answer of questions (item 20) with $\mathrm{M}=3.41$ and $\mathrm{SD}=.701$; or their teacher would correct every mistake they made (item 23) with $\mathrm{M}=3.41$ and $\mathrm{SD}=.700$. In accordance with the survey, the students also revealed the same problems:

"I personally consider that teaching too fast is an important factor that causes students' reticence in theirspeaking performance because the students do not have enough time to answer the questions." (S3); "In my opinion, I assume that some English teachers try to ask their students many difficult questions. Additionally, the students are impossible to answer these questions. As a result, they always feel anxious in responding their teachers as well as speaking to their classmates in English.” (S1) 
Furthermore, another concern that might often create their speaking reticence is the lack of opportunities for students to practice speaking in class, which were rarely provided by their teacher (item 22) with $\mathrm{M}=3.52$ and $\mathrm{SD}=.612$. For instance, some students revealed their opinion about this problem as follows:

"My English teacher rarely creates enough chances for me to practice my speaking skill so I cannot feel confident when speaking in English. Therefore, I do not like communicating in English in class." (S8)

Moreover, they also thought that they did not have any ideas to say because of speaking anxiety when their teacher only asked them to speak in front of the class (item 24) with $\mathrm{M}=3.46$ and $\mathrm{SD}=.644$. Lastly, the lowest mean belongs to item 21 with $\mathrm{M}=3.22$ and $\mathrm{SD}=.824$. In particular, students considered that their teacher had no interesting methods of teaching speaking skills. For instance, some students revealed their opinion about this problem as follows:

"I presume that the interesting pedagogical method of an English teacher is so essential for improving the speaking competence of his or her students. Besides, the teacher also needs to consider about the interests of their students during the English learning process." (S9); "I suspect that incorrect pronunciation, as well as the imposition of teaching methods which only imitate servilely the contents in the textbook, are able to create a stressful and boring feeling when speaking in English." (S10)

In regards to teachers' English attitudes and behaviors, a large number of the students said that they were not willing to communicate in English because of three teacher-related reasons including their teacher always interrupts them to correct mistakes, forced them to speak as quickly as possible, and also created a stressful atmosphere in the English class (item 28, 29, and 30) with $\mathrm{M}=3.63,3.71 \& 3.64$ and $\mathrm{SD}=.588, .468 \& .561$ respectively. For example, some students considered about this situation:

"TheEnglish teacher always asks students to use English in class. Particularly, the students are not motivated to answer questions of their teacher in English because they feel very stressed. As a result, they cannot be able to communicate in
English." (S5); "From my view, I consider that a teacher whose behaviors are negative can make their students feel stressful when being asked. Particularly, they are not willing to say anything in English because of the interruptions of the teacher for correcting their mistakes." (S4)

The next high mean belongs to item 26, which is the teacher never accepted students' ideas when they were wrong with $\mathrm{M}=3.60$ and $\mathrm{SD}=.627$. Additionally, another two concerns related to the attitudes and behaviors of their teacher, which had significant effects on their speaking reticence, are the English teacher did not respect what students said and responded in a friendly way (item 25) with $\mathrm{M}=3.43$ and $\mathrm{SD}=.682$; or the teacher also had negative gestures and harsh comments on the students' performance (item 27) with $\mathrm{M}=3.39$ and $\mathrm{SD}=$ 677.Particularly, some students expressed their agreement on this situation as follows:

"In my opinion, the attitude of English teacher toward the speaking mistake of his or her students can affect directly their speaking willingness in class. In particular they also feel disappointed when saying something wrong."(S6)

Obviously, the discouragement of the teacher when students speaking in English is also the main factor because most of the students thought that they did not willing to speak in English unless their teacher encouraged them (item 31) with $\mathrm{M}=3.27$ and $\mathrm{SD}=.770$. In the interview, $\mathrm{S} 7$ agreed with this:

"The discouragement and unfriendliness of the teacher are two principal factors that influence easily on the speaking performance of a student." (S7)

The data collected from three class observations also revealed that several factors caused reticence among students relating to their teacher. For example, when observing CL2 on March $6^{\text {th }}$, 2021, the researcher discovered that the teachers usually used both Vietnamese language and English language to teach the lesson. However, the teacher did not use other materials rather than textbooks to give students more opportunities to practice their speaking skill. In addition, the teacher did not encourage students to participate in class and rarely created speaking tasks for students work in groups or pairs. Furthermore, the teacher did not give their students enough time for completing the exercises in textbook as well as practicing their speaking skill with their partner.

Context-related factors

Table 6:Descriptive statistics of context-related factors

$\begin{array}{llr}\text { No. Items } & \mathbf{N}=\mathbf{1 4 7}\end{array}$




\begin{tabular}{|c|c|c|c|}
\hline & & & \\
\hline & & $\mathbf{M}$ & SD \\
\hline 32 & $\begin{array}{l}\text { The atmosphere in my English class is not encouraging and } \\
\text { attractive. }\end{array}$ & 3.53 & .565 \\
\hline 33 & There are too many students in my class. & 3.52 & .623 \\
\hline 34 & $\begin{array}{l}\text { Speaking activities are really boring. Only some students } \\
\text { speak English. }\end{array}$ & 3.27 & .634 \\
\hline 35 & There is too much noise inside and outside the class. & 3.67 & .501 \\
\hline 36 & English speaking skills are not tested during the course. & 3.65 & .532 \\
\hline 37 & $\begin{array}{l}\text { I feel overwhelmed by the number of rules for communication } \\
\text { in English in the textbook. }\end{array}$ & 3.52 & .634 \\
\hline 38 & $\begin{array}{l}\text { The textbook does not have many activities for students to } \\
\text { practice speaking. }\end{array}$ & 3.59 & .583 \\
\hline 39 & $\begin{array}{l}\text { The topics in the textbook are too difficult for me to talk } \\
\text { about. }\end{array}$ & 3.62 & .577 \\
\hline 40 & $\begin{array}{l}\text { The topics in the textbook are not interesting enough to attract } \\
\text { me. }\end{array}$ & 3.59 & .572 \\
\hline
\end{tabular}

As demonstrated in Table 6, some context-related factors which might cause students' reticence in their speaking performance including: 5 items relating to class environment (items 32, 33, 34, 35\&36) and 4 items relating to textbook (items $37,38,39 \& 40$ )

In addition, regarding class environment, the mean score for item $35(M=3.67)$ and item $36(M=3.65)$ are very high, which means most students strongly agree that there was too much noise inside and outside the class (item 35) with $\mathrm{M}=3.67$ and $\mathrm{SD}=.501$ ) as well as English speaking skills were not tested during the course (item 36) with $\mathrm{M=}$ 3.65 and $\mathrm{SD}=.532$. In the interview, two students agreed with this:

"The noisy atmosphere of the English class not only creates a lot of distractions for students but also affects on their English learning attitude." (S4); "I think a large number of students in class is the main factor which can cause students' speaking reticence." (S5)

The next two factors which usually caused speaking reticence of most students are the discouraging and unattractive class atmosphere (item 32 ) with $\mathrm{M}=3.53$ and $\mathrm{SD}=.565$, and a large number of students in each class (item 33) with $\mathrm{M}=3.52$ and $\mathrm{SD}=.623$. For instance, some students revealed their opinion about these problems as follows:

"The appropriate number of students in each English class is one of the most significant factors. In my opinion, the more students in class, the more reticent they are." (S7); "About the atmosphere in English class, I consider that the students are not willing to speak in English if they learn in an unexciting and exhausting class." (S2); "The habitof using Vietnamese in the English classes of manystudents is the factor that influences mainly on other students' willingness of speaking in English." (S7); "In my opinion, the interesting class atmosphere is so important for the English learning development of the students."(S10); "Personally, I consider that a class with too many students makes the student feel more nervous while speaking in English." (S6)

Finally, one more factor relating to the class environment which sometimes makes students feel reticent when expressing their opinions in English is the speaking activities in class were boring, therefore only some students spoke English (item 34) with $\mathrm{M}=3.27$ and $\mathrm{SD}=$ .634. For example, some students considered this situation:

"From my own point of view, the interesting learning atmosphere, which is created by the speaking activities, is very necessary for the improvement of students' English learning proficiency." (S9)

With reference to the textbook, the highest mean score goes for item 39 with $\mathrm{M}=3.62$ and $\mathrm{SD}=.577$ which means that a large number of students agreed that the topics in the textbook were too difficult for student to talk about. In the interview, S5 also considered his opinion about this problem as follows:

"I think many contents or topics in the textbook are too difficult for students to understand. As a result, it is hard for them to explain their ideas about these topics." (S9)

Additionally, the next two high means belong to item 38 with $\mathrm{M}=3.59$ and $\mathrm{SD}=.583$ and item 40 with $\mathrm{M}=3.59$ and 
$\mathrm{SD}=.572$. In particular, students strongly agreed that the textbook did not have many activities for students to practice speaking (item 38 ), and the topics in the textbook were not interesting enough to attract students (item 40). For instance, S3 revealed his opinion about these problems as follows:

"From my point of view, I think that the motivation of the contents in the English textbook is so crucial to their English learning process because students are willing to communicate more in English when they feel interested in learning. Furthermore, they do not want to speak in English because there are no activities for them to practice their speaking skill in the textbook" (S3)

Last but not least, students also considered that the number of rules for communication in English in the textbook made students feel overwhelmed (item 37) with $\mathrm{M}=3.52$ and $\mathrm{SD}=.634$. Particularly, S5 expressed his idea about this problem as follows:

“... Additionally, they feel exhausted to speaking or using English in real-life situations when they read the textbook because there are too many communication rules in English." (S5)

In conclusion, the result in Table 7 reveals that the total mean scores of the factors causing students' reticence were high $(\mathrm{M}=3.48 ; \mathrm{SD}=.66)$.

Table 7:Factors causing reticence for non-English majored students in English speaking performance

\begin{tabular}{llll}
\hline \multirow{2}{*}{ No. } & \multirow{2}{*}{ Factors } & $\mathbf{N}=\mathbf{1 4 7}$ & \\
\cline { 3 - 4 } & & $\mathbf{M}$ & $\mathbf{S D}$ \\
\hline 1 & Student-related factors & 3.47 & .67 \\
2 & Classmate-related factors & 3.42 & .73 \\
\hline 3 & Teacher-related factors & 3.48 & .65 \\
\hline 4 & Context-related factors & 3.55 & .58 \\
\hline Total & & $\mathbf{3 . 4 8}$ & $\mathbf{. 6 6}$ \\
\hline
\end{tabular}

As can be seen in Table 7, the most influential factors, which created the speaking reticence of students in class, related to the context. The other less effective factors including teacher-related factors $(\mathrm{M}=3.48 ; \mathrm{SD}=.65)$, student-related factors $(\mathrm{M}=3.47 ; \mathrm{SD}=.67)$, and classmaterelated factors $(\mathrm{M}=3.42 ; \mathrm{SD}=.73)$.

\subsection{Discussion}

Regarding the extent of students' reticence in English speaking performance, the findings of the study revealed that most of the students seemed to be reticent when speaking English with their teacher as well as their classmates in class. These findings are in line with those of several previous studies. For example, Nguyen(2010) considered in his research that instead of volunteering to answer in English the questions of their teacher, students usually keep quiet and wait until called; or Merve (2014) also concluded that nervousness couldcause reticence among students. Another aspect is that most students agreed that they did not dare to say or answer questions of their teacher in English and they felt nervous. Therefore, they avoided seeing their teachers' faces. Liu (2007) also pointed out that a major number of students feel more anxious when giving presentations or answering questions in English. In addition, a large number of students agree that they prefer to remain silent rather than to speak English in class to avoid any embarrassing situation. This finding is consistent with that of Davies and Pearse (2000) revealing that students worry about making errors by producing English utterances incorrectly. Obviously, these aspects can create speaking reticence for students in class.

In term of the factors causing reticence for nonEnglish majored students in English speaking performance, the findings of the study revealed that the students have experienced many problems relating to themselves, their classmates, their teacher, and the context which might also be thereaons why students are not willing to speak in English in class.Particularly, findings from this study indicated that context-related factors have a more considerable influence on the speaking reticence of non-English majored students than the other factors. More specifically, five major issues arose regarding the class environment and four major issues arose from the textbook. In particular, two main majors relating to the class environment are that there was too much noise inside and outside the class and the unattractive atmosphere in their English class. Some consistent situations are documented in a study byPattapong (2010), Peng (2014), and Suksawas (2011) which revealed that a boring classroom atmosphere can demotivate the speaking willingness of students while a friendly one can promote their willingness to communicate. In addition, the issue relating to the textbook, which is the topics in the textbook were too difficult and too boring for students to talk about, can create a negative impact on students' speaking 
performance. Most of the students have negative perceptions of the contents in the textbook because they are too hard for them, leading to the reticence of the students. This finding is supported by the study of Dao (2017) which stated that the students were rarely willing to speak English in class because they found the topics less exciting for them to do and talk about. In particular, the contents in the textbook were also difficult, not updated, and irrelevant to the Vietnamese context so students easily found these topics boring to complete.

In respect of teacher-related factors, teachers' attitudes and behaviors seem to have more impact than teachers' teaching methods, in particular, the attitudes of the teacher toward correcting students' mistakes. This finding is consistent with the study byLe and Tran (2020) who also implied that the more teachers who teach English in Vietnamese universities behave positively when correcting speaking mistakes of the students and understand their students' personality and preferences, the more they can support their students in the improvement of their speaking willingness in English.

With reference to student-related factors, this factor was found to have a certain influence on the speaking reticence of the students. This is in line with the finding from Urrutia and Vega's study (2006) revealing that lack of confidence as well as vocabulary, and the fear of making mistakes are three main factors that cause reticence of the students in their English class. Moreover, students are able to compare themselves with other classmates so the feeling of having lower English proficiency than their classmates makes them not want to express their ideas in English.

In respect of classmate-related factors, the finding of this study indicated that some issues relating to the feeling of being laughed at by other classmates have considerable impacts on their speaking willingness in class. This finding is supported by the study of Liu (2007) who showed that because students were afraid of making mistakes and being laughed at by their classmates, most of the students easily lost their speaking confidences when they were in front of others and could not say any words. Furthermore, To and Lai (2019) pointed out that public speaking fear is one of the main factors that created the students speaking reticence in class.

\section{CONCLUSION AND IMPLICATIONS}

It can be concluded that the extent of the students in their English-speaking performance was expressed clearly through the data which were collected from the questionnaires, semi-structured interview, and class observations and that most of the students were reticent about speaking English to a rather high extent. That is because speaking reticence was caused by student-related, classmate-related, teacher-related andcontext-related factors.

Based on the findings of the study, it is recommended that teachers should provide their students with more time to work in groups in order to complete speaking activities. Besides, they also need to pay attention to sharing their ideas with some special students who need more supports. Additionally, teachers should prepare diverse speaking activities to motivate class discussion and group discussions which are not only interesting but also creative to attract students' attention to practicing their English speaking skills in class. As a result, the speaking reticence can be reduced in English classes. Last but not least, teachers should create more motivation for students to improve their speaking confidence in a number of effective ways such as providing students some authentic materials to expand not only their vocabulary but also their topical ideas. Therefore, students can have more knowledge and essential words to explain easily their opinions in English. For EFL students, it is recommended that to reduce their speaking reticence in their English classes, students should spend more time for self-study before and after the class and give more focus on practicing their speaking skills and they should expand their vocabulary as well as their knowledge by reading more books about vocabulary in use. In addition, they should work more in groups and interact with teachers and other classmates in their English classrooms.

This study was conducted at only one university with the participation of 147 students, so limitations cannot be avoided. It is suggested that another study can be conducted at several universities with more EFL students so that the findings would be reliable.

\section{REFERENCES}

[1] Achbi, F. Z., \&Sebaa, K. (2011). Enhancing foreign language students' speaking performance through overcoming anxiety. (UnpublishedMaster's thesis). Biskra University, Algeria.

[2] Aftat, M. (2008). Motivation and genuine learning.Retrieved

fromhttp://www.englishteacher1.com/motivation.html

[3] Al Hosni, S. (2014). Speaking difficulties encountered by young EFL learners. International Journal on Studies in English Language and Literature (IJSELL),2(6).

[4] Burgoon, J. K. (1976). The unwillingness to communicate scale: Development and validation. Communication monographs, 43, 60-69.

[5] Dao,ThiThanhHao (2017). Identify factors that negatively influence: Non-english major students' speaking skills Higher Education Research, 2 (2), 35-43. Retrieved fromhttp://www.sciencepublishinggroup.com/ 
[6] Davies, P. \&Pearse, E. (2002). Success in English teaching. Shanghai Foreign Language Education Press.

[7] Fang-yu, C. (2011). The causes of learners' reticence and passivity in english classrooms in taiwan. The Journal of Asia TEFL, 8 (1), 1-22. Retrieved fromhttp://journal.asiatefl.org/

[8] Garrison, D. R. \& Shale, D. (1990). A new framework and perspective. In Garrison, D. R. \& Shale, D. (Eds). Education at a distance: From issues to practice (p. 123133). Malabar, FL: Robert E. Krieger.

[9] Gebhard, G. J. (2000). Teaching English as a foreign or second language. USA: The University of Michigan Press.

[10] Hamouda, A. (2013). An exploration of causes of Saudi students' reluctance to participate in the English language classroom. International Journal of English Language Education, 1 (1), 17-34. Retrieved from http://www.macrothink.org/

[11] Hedge, T. (2000). Teaching and learning in language classroom. Oxford: Oxford University Press.

[12] Horwitz, E. K., Horwitz, M. B., \& Cope, J. (1986). Foreign language classroom anxiety. The Modern Language Journal, 70(2), 125-132.

[13] Hutchinson, T., \& Waters, A. (1987). English for specific purposes: A learner-centered approach. Cambridge: Cambridge University Press.

[14] Kanar, C. C. (2011). The confident student (7th ed.). Boston, MA: Wadsworth Cengage.

[15] Kurtus, R. (2001). Overcome the fear of speaking to group. Available at http://www.school-forchampions.com/speaking/fear.htm

[16] Le, Van Tuyen\&Tran,ThiTrang Loan (2019). Factors affecting EFL students' willingness to communicate in speaking classes at Vietnamese tertiary level. International Journal on Studies in English Language and Literature, 4(2), 252-262. Available at http://dx.doi.org/10.22161/ijels.4.2.10

[17] Liu, M. (2007). Anxiety in oral English classrooms: A case study in China. Indonesian Journal of English Language Teaching, 3(1), 119-137.

[18] McCombs, B. L., \&Whisler, J. S. (1997). The learnercentered classroom and school: Strategies for increasing student motivation and achievement. San Francisco, CA: Jossey-Bass Inc.

[19] McCroskey, J. C. (1976). The effects of communication apprehension on nonverbal behavior. Communication Quartley, 24, 39-45.

[20] McCroskey, J. C., Richmond, V. P., Daly, J. A., \&Falcione, R. L. (1977). Studies of the relationship between communication apprehension and self-esteem. Human Communication Research, 3(3), 269-277.

[21] Merve, S. (2014). Why are some students reluctant to use L2 in EFL speaking classes? An action research at tertiary level. Procedia - Social and Behavioral Sciences, 26822686.

Available at http://dx.doi.org/10.1016/j.sbspro.2014.01.635
[22] Muhamad, A. (2020). An analysis of the English students' speaking anxiety in research proposal seminar. Retrieved from https://www.researchgate.net/publication

[23] Nguyen, Hieu (2011). Linear subspace methods in face recognition. $\mathrm{PhD}$ thesis, University of Nottingham.

[24] Nguyen, Minh Hue (2010). Encouraging reluctant ESL/EFL learners to speak in the classroom. The Internet TESL Journal, 16(3). Retrieved from http://iteslj.org/Techniques/NguyenReluctantSpeakers.html

[25] Nunan, D. (1999). Second language teaching and learning. USA: Heinle and Heinle Publisher. [ic

[26] Pattapong, K. (2010). Willingness to communicate in a second language: A qualitative study of issues affecting Thai EFL learners from students' and teachers' point of view. (Unpublished Doctoral Dissertation). University of Sydney. $\quad$ Retrieved from https://ses.library.usyd.edu.au/bistream/2123/9244/1/

[27] Peng, J. (2014). Willingness to communicate in Chinese EFL university classroom: An ecological perspective. Bristol: Multilingual Matters.

[28] Riasati, M. J. (2014). Causes of reticence: Engendering willingness to speak in language classroom. International Journal of Research Studies in Language Learning, 3(1), 115-122.

[29] Robby, S. (2010).Conquer your fear of making mistakes when speaking English. Retrieved from http://englishharmony.com/conquer-fear-of-makingmistakes-when-speaking-English/

[30] Saurik (2011). Learning English the easy way!. Retrieved from http://guides.wikinut.com/Learning-English-TheEasy-Way!/2wuchx26/

[31] Soo, R. S.\&Goh, H. S. (2013). Reticent students in the esl classrooms. Advances in Language and Literary Studies, 4 (2), 65-73. Retrieved from https://www.journals.aiac.org.au/

[32] Suksawas, W. (2011). A sociocultural study of elflearners' willingness to communicate.(Unpublished Doctoral Dissertation). Faculty of Education.University of Wollongong. Retrieved fromhttps://ro.uow.edu.au/theses

[33] Tavakoli, E. \& Davoudi, M. (2017). Willingness to communicate orally: The case of Iranian elf learners. Journal of Psycholinguistic Research , 46 (6), 1509-1527. Available at https://doi.org/10.1007/s10936-017-9504-0

[34] Thornbury, S. (2005). How to teach speaking. Essex: Pearson Education Limited.

[35] To,Thi Le \& Lai,HoaiChau (2019). Identifying the effect of socio-cultural factors on pre-intermediate students' reticence in speaking English. Research Journal of English Language and Literature, 7(2), 211-219.

[36] Urrutia, W., \& Vega, E. (2006). Encouraging teenagers to improve speaking skills through games in a Colombian public school. Profile Issues in Teachers' Professional Development Journal, 12(2).

[37] Wrench, J. S., Goding, A., Johnson, D. I., \&Attias, B. A. (2012). Public speaking: Practice and ethics. Retrieved from https://2012books.lardbucket.org/pdfs/publicspeaking-practice-and-ethics.pdf 
[38] Young, D. J. (1991). Creating a low-anxiety classroom environment: What does language anxiety research suggest?.The Modern Language Journal, 75(4), 426-439. 